\title{
Follistatin induction by nitric oxide through cyclic GMP: a tightly regulated signaling pathway that controls myoblast fusion
}

\author{
Addolorata Pisconti, ${ }^{1}$ Silvia Brunelli, ${ }^{1,2}$ Monica Di Padova, ${ }^{3}$ Clara De Palma, ${ }^{1,7}$ Daniela Deponti, ${ }^{1,4}$ Silvia Baesso, ${ }^{1}$ \\ Vittorio Sartorelli, ${ }^{3}$ Giulio Cossu, ${ }^{1,5,6}$ and Emilio Clementi ${ }^{1,4,7}$ \\ 'Stem Cell Research Institute, Hospital San Raffaele, 20132 Milan, Italy \\ ${ }^{2}$ Department of Experimental Environmental Medicine and Medical Biotechnology, University of Milano-Bicocca, 20052 Monza, Italy \\ ${ }^{3}$ Muscle Gene Expression Group, Laboratory of Muscle Biology, National Institute of Arthritis and Musculoskeletal and Skin Diseases, National Institutes of Health, \\ Bethesda, MD 20892 \\ ${ }^{4}$ Eugenio Medea Scientific Institute, 23842 Bosisio Parini, Italy \\ 5 Institute of Cell Biology and Tissue Engineering, San Raffaele Biomedical Science Park of Roma, 00128 Rome, Italy \\ 'Department of Biology, University of Milano, 20130 Milan, Italy \\ 7 Department of Preclinical Sciences, University of Milano, 20157 Milan, Italy
}

$\mathrm{T}$ he mechanism of skeletal myoblast fusion is not well understood. We show that endogenous nitric oxide (NO) generation is required for myoblast fusion both in embryonic myoblasts and in satellite cells. The effect of NO is concentration and time dependen being evident only at the onset of differentiation, and o rect on the fusion process itself. The action of 13 edi ated through a tightly regulated actions cyclase and generation of cydic alno e mabhosphate (cGMP), so much so th ogula

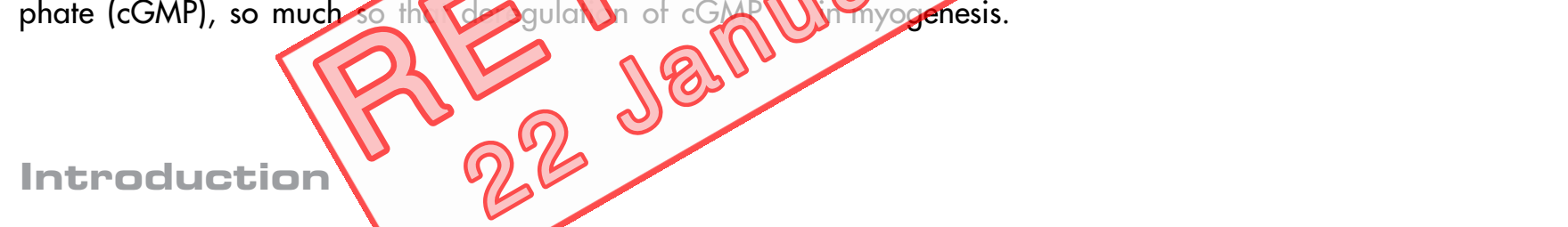

Skeletal muscle tissue is composed of nontinucleated fibers that arise at defined periods of anbyogenesis from fusion of myoblasts (Buckingham et al., 2003). In particular, embryonic and fetal myoblasts, originating from different waves of myoblasts (Cusella-De Angelis et al., 1994; Relaix et al., 2005), give rise to primary (at about embryonic day [E] 11-12) and

\footnotetext{
Correspondence to E. Clementi: clementi.emilio@hsr.it or; G. Cossu: guilio.cossu@hsr.it

A. Pisconti and S. Brunelli contributed equally to this paper.

Abbreviations used in this paper: $B M P$, bone morphogenetic protein; CREB, CAMP response element binding protein; cGMP, cyclic guanosine monophosphate; DETA-NO, (Z)-1-[2-(2-aminoethyl)-N-(2-ammonioethyl)amino]diazen1-ium-1,2-diolate]; E, embryonic day; Fs-luc, luciferase gene; GAPDH, glyceraldehyde3-phosphate dehydrogenase; IGF, insulin-like growth factor; IL-4, interleukin 4; L-NAME, N ${ }^{\omega}$-nitro-t-arginine methyl ester; $M L C 1 / 3 F$, myosin light chain promoter 1/3 fast; NFAT, nuclear factor of activated T cells; NO, nitric oxide; NOS, nitric oxide synthase; ODQ, $1 H(1,2,4)$ oxadiazolo [4,3- $\alpha$ ]quinoxalin-1-one; PCNA, DNA polymerase $\delta$ cofactor; PSM, presomitic mesoderm; (Rp)-8-pCPTcGMPS, 8-(chlorophenylthio) guanosine-3', $5^{\prime}$ - cyclic monophosphorothioate; TSA, trichostatin A.

The online version of this article contains supplemental material.
}

secondary (at about E15-16) fibers, respectively (Ontell and Kozeka, 1984). Subsequently, muscle masses undergo extensive growth in the fetal and postnatal period, and this growth is supported by specialized cells, the satellite cells, situated within a niche between the plasmalemma and the basal lamina of fibers (Tajbakhsh, 2003). Throughout myogenesis, a fine balance among proliferation, differentiation, and fusion is required for the correct formation of the definitive muscle units (Tatsumi et al., 2002; Buckingham et al., 2003). Many positive and negative signals responsible for the regulation of such a fine balance have been identified, acting at both embryo/fetal stages and postnatally. These include transcription factors, such as MyoD, Myf5, MRF4, and myogenin, as well as extracellular agonists and antagonists, such as members of the insulin-like growth factor (IGF) and TGF $\beta$ families, FGF, hepatocyte growth factor, and bone morphogenetic protein (BMP) and its antagonists follistatin and chordin (Balemans and Van Hul, 2002; Parker et al., 2003). 
The short-lived messenger nitric oxide (NO) regulates key functions of adult skeletal muscle, such as the activity of neuromuscular synapses, excitation-contraction coupling, vasodilation, glucose uptake, mitochondrial function and biogenesis, glycolysis, and phosphocreatine breakdown (Wang et al., 1995; Balon and Nadler, 1997; Clementi and Meldolesi, 1997; Wolosker et al., 1997; Bredt, 1998; Stamler and Meissner, 2001; Eu et al., 2003; Nisoli et al., 2004). The possibility that NO plays a role in skeletal myogenesis is suggested by the observations that it participates in satellite cell activation (Anderson, 2000; Tatsumi et al., 2002) and that its synthesizing enzymes, the NO synthases (NOSs), are developmentally regulated and may contribute to the myogenic program activated by IGF-II (Lee et al., 1994; Blottner and Luck, 1998; El Dwairi et al., 1998; Kaliman et al., 1999). The precise role of NO in myogenesis and the signaling pathways acting downstream of it are, however, not known.

In the present study, we investigated these aspects, both in vitro and in vivo, at different phases of myogenesis. Our results show that NO directly stimulates myoblast fusion through the up-regulation of follistatin, defining for the first time a link between NO and another key player in adult and embryonic myogenesis. We also found that the action of NO is limited to a defined time window and is mediated through a tightly regulated activation of guanylate cyclase and generation of cyclic guanosine monophosphate (cGMP), a physiological f- Sion inde concentat Rjependent ways. These effects were

fector of NO (Moncada et al., 1991). Maintenance of cGMP signaling by treatment with 8 Br-cGMP leads to an increased fusion process with generation of hypertrophic myotubes and myofibers in vitro and in vivo. Overall, our results indicate a pivotal role of NO/cGMP in regulating myoblast fusion during muscle development.

\section{Results}

\section{Exogenous and endogenous NO increase satellite cell fusion in vitro in a \\ specific time window}

To study the effects of NO on myoblast differentiation and fusion, satellite cells isolated from newborn mice and plated at low density $\left(6 \times 10^{3}\right.$ cells $\left./ \mathrm{cm}^{2}\right)$ were maintained for $48 \mathrm{~h}$ in growth medium and then switched to the differentiating medium in the presence or absence of increasing concentrations of the NO donor (Z)-1-[2-(2-aminoethyl)- $N$-(2-ammonioethyl)amino]dia zen-1-ium-1,2-diolate] (ETA-NO), which releases NO constantly and at defined rations (Clementi et al., 1998), or $N^{\omega}$-nitro-L-arginin $n$ byl er (L-NAME), which is a broad spectrum in tor al., 1991). The fusion ind $x$ med 48, or $\$$ h. As shown in Fig. 1 A, LE, whereas L-NA IE decreased, the fuFigure 1. NO induces fo
from newborn mice were
and then switched to the dit entiation medi) or absence of increasing con Cells were stained after $72 \mathrm{~h}$ $\mathrm{mAb}$ and the nuclear dye Hoe The fus ind $x$ indicates the expressing cells with more than two nuclei versus the total number of nyclei measured. (B) Same as A, except that satellite cells were exposed or not (NT) to single concentrations of DETA-NO $(50 \mu \mathrm{M})$ and L-NAME $(5 \mathrm{mM})$. The fusion index was measured after 24,48 , or $72 \mathrm{~h}$. (C) Representative images of $B$ showing the effects of $50 \mu M$ DETA-NO and $5 \mathrm{mM}$ L-NAME on satellite cell fusion after $72 \mathrm{~h}$ with respect to those of untreated controls. The staining for myosin is in green (FITC). (D) $5 \mathrm{mM}$ L-NAME and $50 \mu \mathrm{M}$ DETA-NO were added to differentiating satellite cells at the indicated time points. The fusion index was assessed after $72 \mathrm{~h}(n=6)$. (E and F) NOS activity, measured as conversion of L-arginine into L-citrulline $(E ; n=4)$, and NOS I $\mu$ and III expression, measured by Western blotting with specific $m A b s(F)$, in the course of satellite cell differentiation in vitro as described in $A$. The Western blot shown here is representative of four reproducible experiments. (G) MyoD, PCNA, and GAPDH expression measured by Western blotting with specific $\mathrm{mAbs}$ in satellite cells exposed or not for $24 \mathrm{~h}$ in differentiation medium to either $50 \mu M$ DETA-NO or $5 \mathrm{mM}$ L-NAME. Results are representative of four reproducible experiments. (H) Percentage of mononucleated cells, binucleated cells, and multinucleated myotubes expressing sarcomeric myosin (myo) in satellite cells exposed or not for $72 \mathrm{~h}$ in differentiation medium to either $50 \mu \mathrm{M}$ DETA-NO or $5 \mathrm{mM}$ L-NAME as described in A. Values are expressed as percentage over those observed in NT. Error bars represent SEM. *, $\mathrm{P}<0.05 ;{ }^{*}$, $\mathrm{P}<0.01 ;{ }^{*} *$ *, $\mathrm{P}<0.001$ versus NT. Bar, $250 \mu \mathrm{m}$.
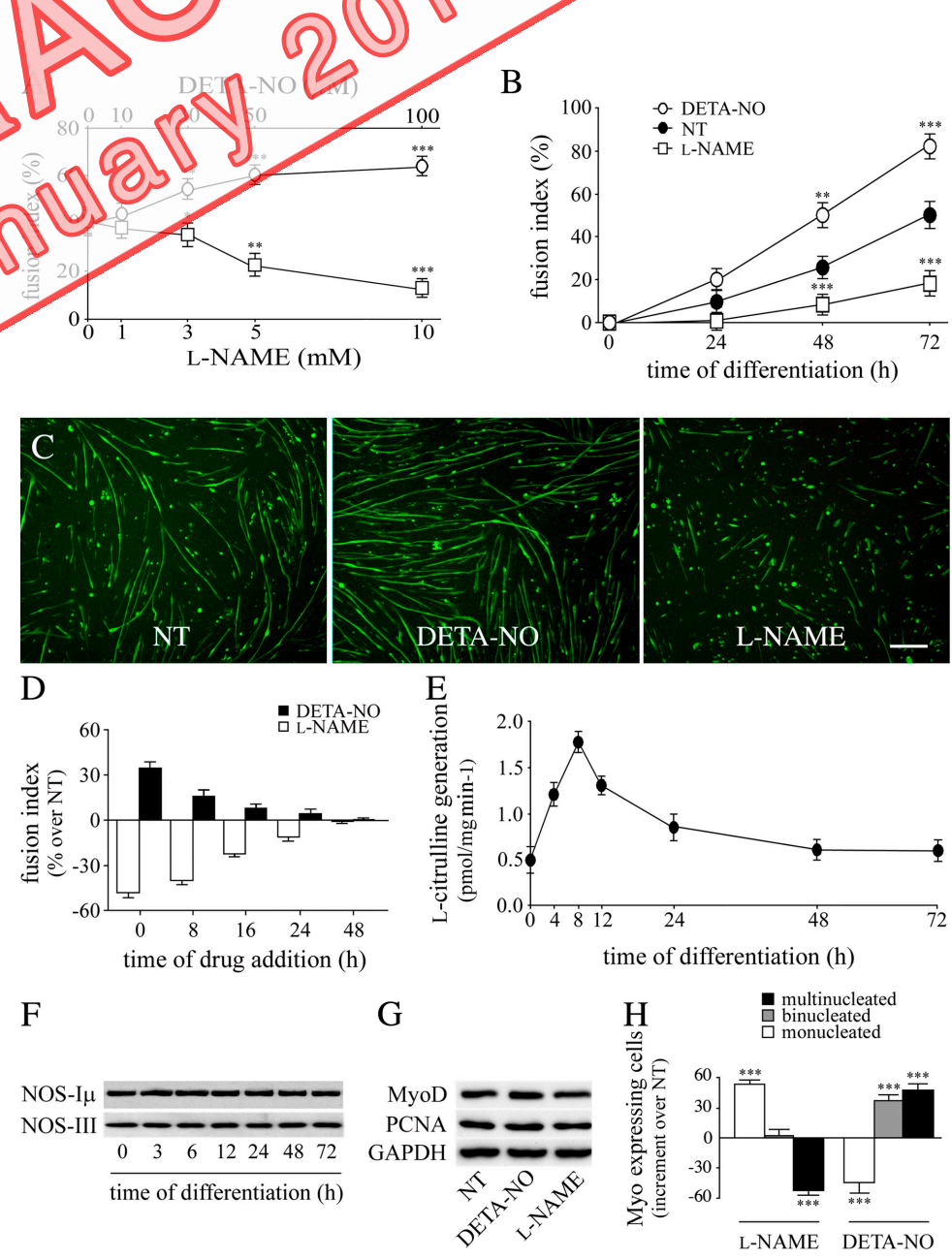
specific because the corresponding amine, DETA, did not yield significant effects and the action of L-NAME was inhibited by $5 \mathrm{mM}$ L-arginine (unpublished data). The stimulation by DETANO and the inhibition by L-NAME were clearly detected after $24 \mathrm{~h}$ and were increased throughout the differentiation program, becoming statistically significant after 48 and $72 \mathrm{~h}$ of culture (Fig. 1, B and C). At 72 h, almost no fusion events were observed among myosin-expressing satellite cells in the presence of $5 \mathrm{mM} \mathrm{L}-\mathrm{NAME}$ (Fig. $1 \mathrm{C}$ ). The fact that the effects of DETA$\mathrm{NO}$ and L-NAME on fusion were already present after $24 \mathrm{~h}$ of treatment suggests that these events took place at an early stage in the differentiation program. To establish the time window of the NO action, $5 \mathrm{mM}$ L-NAME and $50 \mu \mathrm{M}$ DETA-NO (yielding a concentration of $120 \pm 5 \mathrm{nM}, n=5$, measured with a NO electrode; Clementi et al., 1998) were added to differentiating satellite cells at different time points. The fusion index was assessed after $72 \mathrm{~h}$. As shown in Fig. 1 D, both DETANO and L-NAME were maximally effective in enhancing and preventing fusion, respectively, when added at the beginning of the differentiation process. The compounds were progressively less effective when added at later time points and almost completely ineffective when added after $16 \mathrm{~h}$. Consistently, we found that the differentiation process was accompanied by an early increase in NOS activity that peaked at $8 \mathrm{~h}$ and decreased thereafter, returning to basal levels after $48 \mathrm{~h}$ (Fig. $1 \mathrm{E}$ )
We found that satellite cells express the endothelial (NOS III) and muscular (NOS I $\mu$ ) variants of the neuronal NOS. The levels of expression of NOS III and I $\mu$ were unchanged throughout the differentiation process (Fig. $1 \mathrm{~F}$ ), indicating that the changes in NOS activity were the consequences of activation and inhibition of enzyme activity and not of changes in protein expression. NOS II expression was never detected throughout the time window analyzed (unpublished data).

Satellite cells cultured in vitro are asynchronous, with a small portion of them still persisting as undifferentiated cells even after several days in differentiating medium (Cossu et al., 1980; Ontell and Kozeka, 1984). The increased fusion of satellite cells triggered by NO may be attributable to an effect of this messenger on the process itself or secondary to NO-dependent recruitment of the undifferentiated cells into terminal differentiation (Anderson, 2000). This should result in an increase in MyoD expression and a concomitant decrease in cell proliferation. To discriminate between these possibilities, we examined the effects of NO on these proces des. As shown in Fig. 1 G, exposure of satellite cellenly 24 to either $5 \mathrm{mM} \mathrm{L-NAME}$ or $50 \mu \mathrm{M}$ DETA- ged expression of the myogenic prark 1 . factor
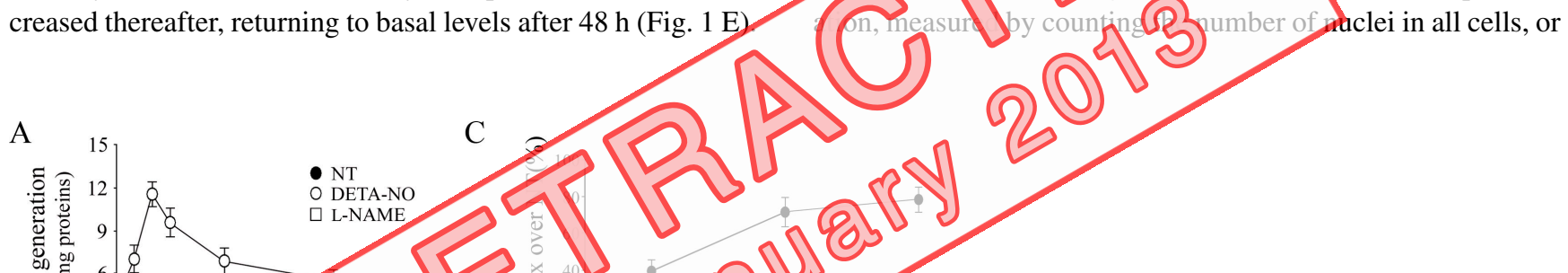

B

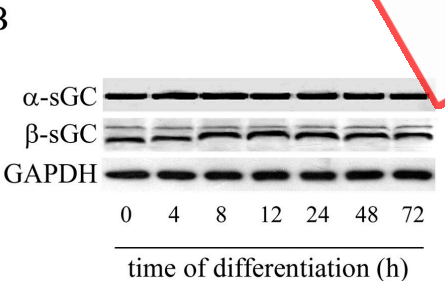

time of differentiation $(\mathrm{h})$
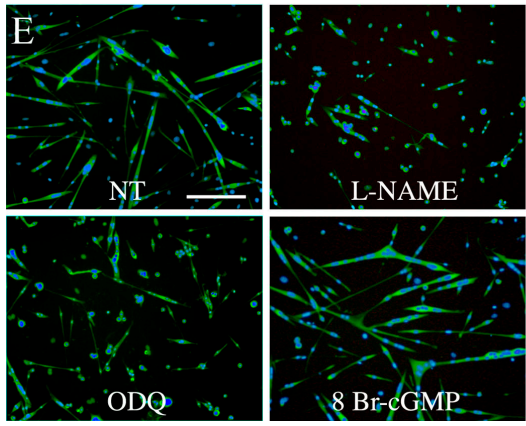

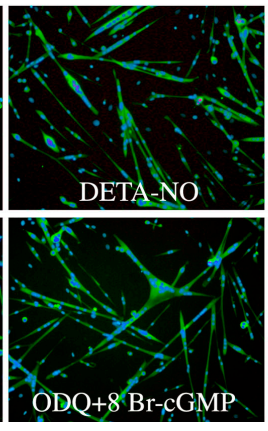

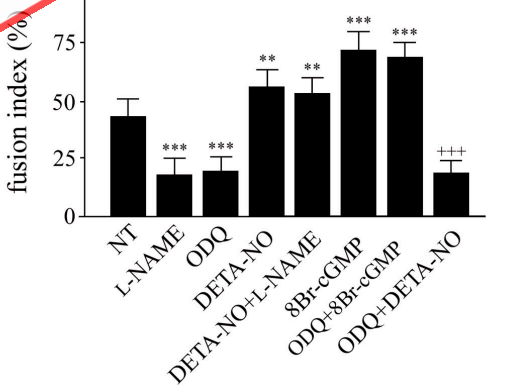

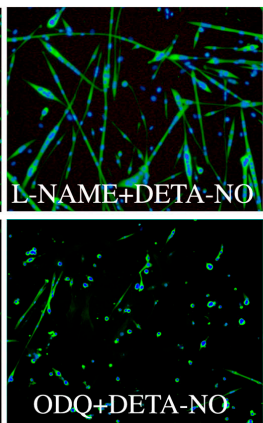

Figure 2. The effect of NO on satellite cell fusion depends on cGMP generation. (A and B) Satellite cells were maintained for $48 \mathrm{~h}$ in growth medium and then switched to the differentiation medium for up to $72 \mathrm{~h}$. (A) Guanylate cyclase activity, measured as formation of cGMP after stimulation with or without (NT) $50 \mu \mathrm{M}$ DETA-NO or $5 \mathrm{mM}$ L-NAME administered for $30 \mathrm{~min}$ at the indicated time points $(n=4)$. (B) Expression of soluble guanylate cyclase and GAPDH (loading control), measured by Western blotting with mAbs specific for the $\alpha$ and $\beta$ subunits of the enzyme. Results are representative of four reproducible experiments. (C) Satellite cell differentiation was performed as described in $A$ for $72 \mathrm{~h}$ in the presence of an increasing concentration of $8 \mathrm{Br}-\mathrm{cGMP}$. The fusion index was measured as described in Fig. 1 $(n=4)$. (D and E) Same as in C except that satellite cell differentiation was performed for $72 \mathrm{~h}$ in the presence or absence of $5 \mathrm{mM}$ L-NAME, $50 \mu \mathrm{M}$ DETA-NO, $3 \mu \mathrm{M}$ $\mathrm{ODQ}$, or $3 \mathrm{mM} 8 \mathrm{Br}-\mathrm{cGMP}$ in various combinations as detailed in the key to the panels. Fusion index was measured as described in Fig. 1. Representative images are shown in E. Anti-sarcomeric myosin MF20 mAb is in green (FITC), and the nuclear dye Hoechst in blue. ${ }^{* *}, \mathrm{P}<0.01$ versus $\mathrm{NT}_{;}{ }^{* * *}, \mathrm{P}<0.001$ versus NT; $\dagger, \mathrm{P}<0.001$ versus 8 Br-cGMP-treated cells $(n=6)$. Error bars represent SEM. Bar, $200 \mu \mathrm{m}$. 

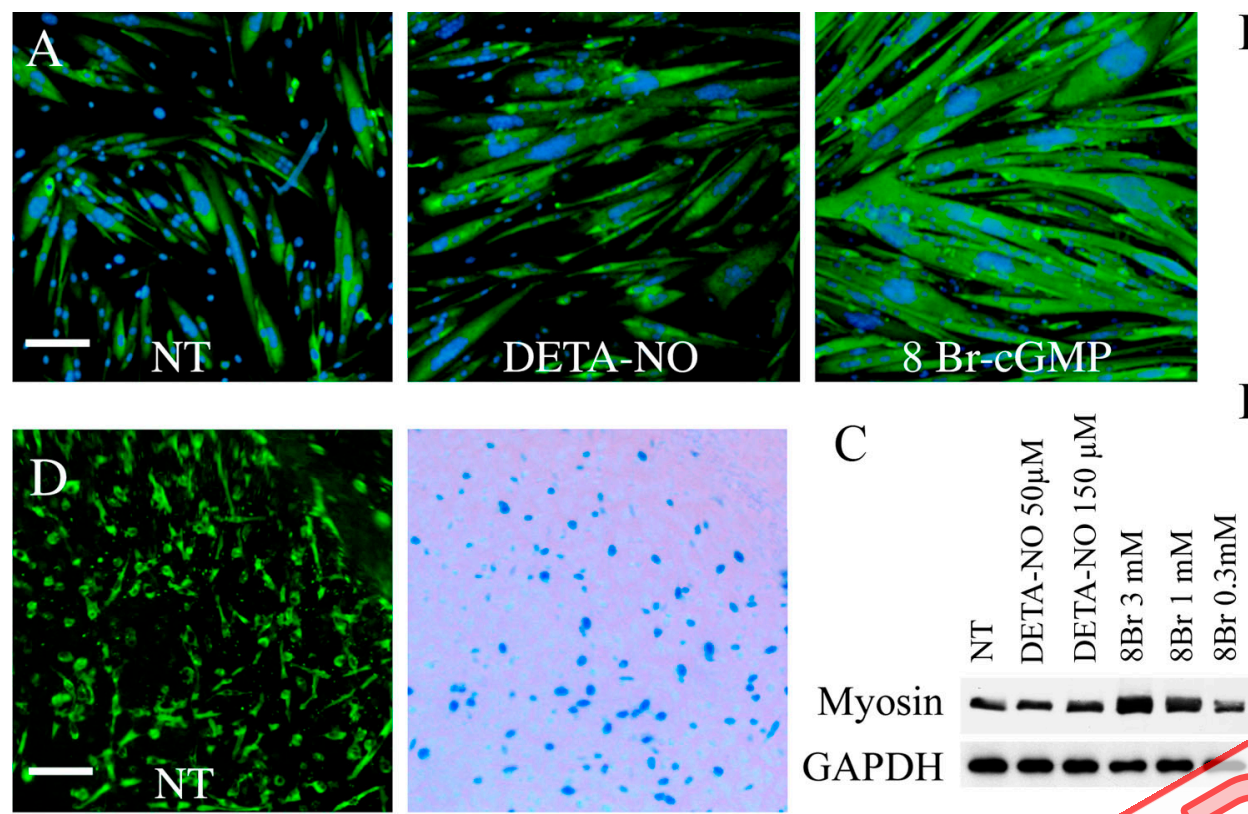

$\mathrm{E}$
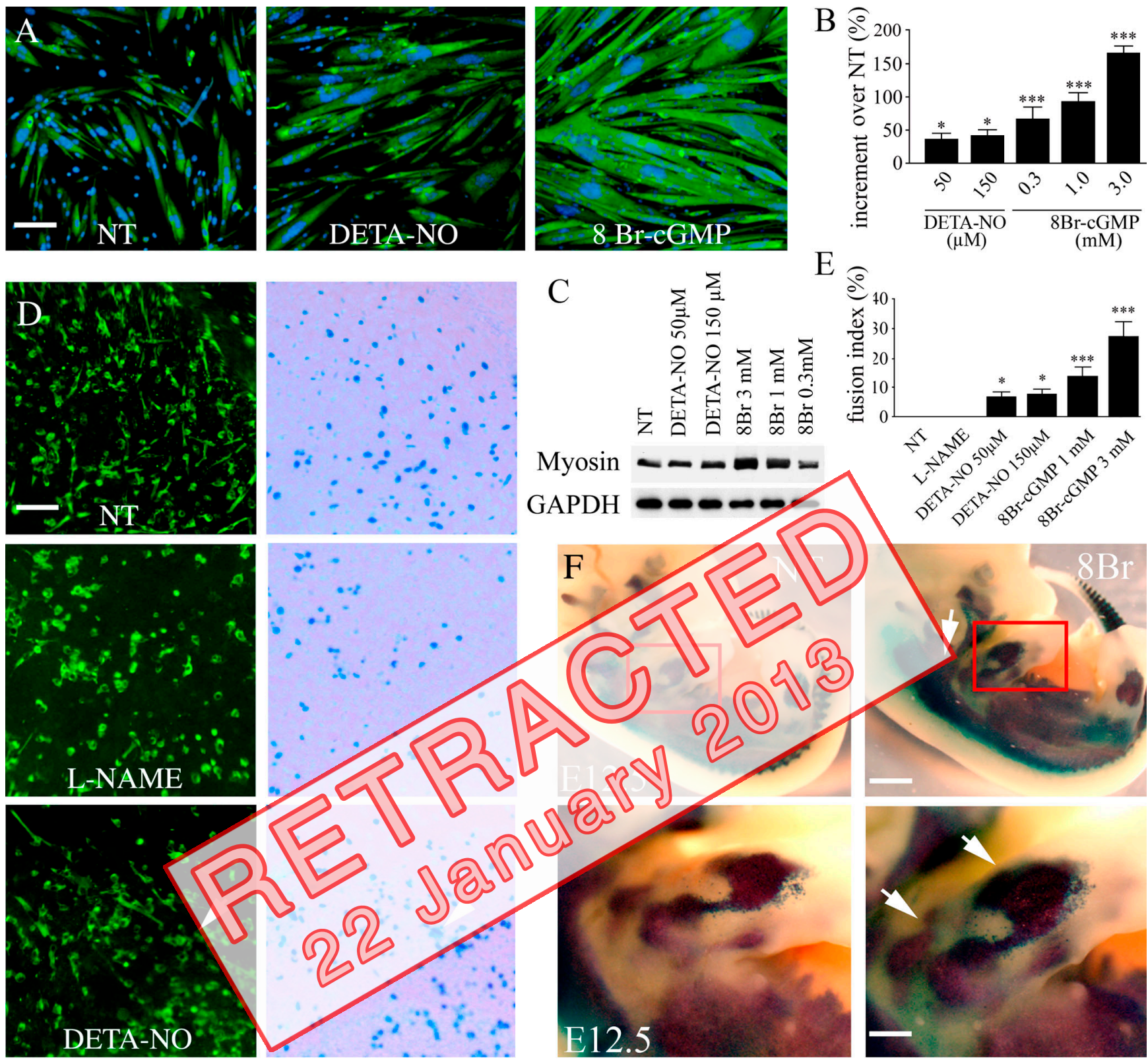

\section{GAPDH}
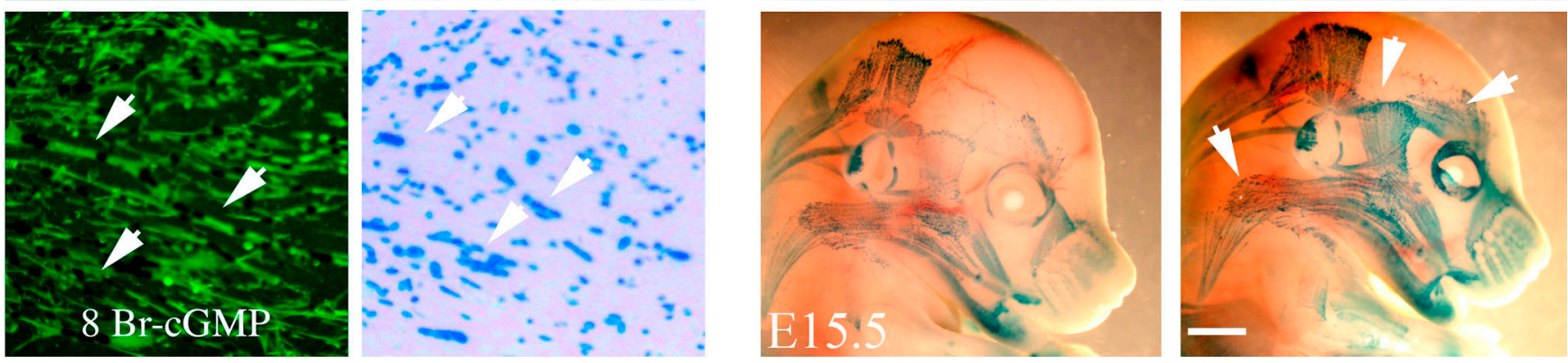

Figure 3. Persistence of cGMP leads to fusion-induced muscle hypertophy at different stages of muscle development. (A-C) Satellite cells from newborn mice were plated at high density $\left(3 \times 10^{4}\right.$ cells $\left./ \mathrm{cm}^{2}\right)$, maintained for $48 \mathrm{~h}$ in growth medium, and switched to the differentiation medium in the presence or absence of 50 or $150 \mu \mathrm{M}$ DETA-NO or $0.3,1.0$, or $3.0 \mathrm{mM} 8$ Br-cGMP. After $48 \mathrm{~h}$, cells were either stained with the anti-sarcomeric myosin MF20 $\mathrm{mAb}$ (green, FITC) and the nuclear dye Hoechst (blue) or processed for Western blot analysis. (A) Representative images of four reproducible experiments ( $3 \mathrm{mM} 8 \mathrm{Br}-\mathrm{cGMP}$ and $50 \mu \mathrm{M}$ DETA-NO). 10× magnification. (B) Percentage of nuclei containing $>12$ nuclei, calculated as depicted in Fig. 1. *, $\mathrm{P}<0.05$; $\star * *, P<0.001$ versus untreated cells (NT; $n=4$ ). (C) Sarcomeric myosin (myosin) and GAPDH expression, determined by Western blotting (one out of four reproducible experiments). (D and E) PSM explants from MLC1/3F-nLacZ E9.5 embryos were differentiated for $4 \mathrm{~d}$ in the presence or absence of 50 or $150 \mu$ M DETA-NO, $5 \mathrm{mM}$ L-NAME, or 1 or $3 \mathrm{mM} 8 \mathrm{Br}$-cGMP. (D, left) Immunofluorescence using the anti-sarcomeric myosin MF20 mAb (green, FITC). The myogenic nuclei are labeled by X-Gal staining (dark blue). (right) Same fields as in the left panels, but the X-Gal staining is merged with Hoechst staining (light blue), labeling all nuclei. Arrows demarcate multinucleated myotubes, which are absent in untreated explant cultures and frequent in cultures 
the number of nuclei present in myosin-positive cells (unpublished data). This excludes the possibility that the formation of hypernucleated myotubes with increased size was a consequence of an increased number of undifferentiated myogenic cells recruited to terminal differentiation, suggesting that $\mathrm{NO}$ acts directly as an inducer of myoblast fusion.

The process whereby myogenic cells generate myofibers is the consequence of the initial fusion between two myoblasts and the subsequent fusion of new cells to the initial two-cell myotube (Charge and Rudnicki, 2004). As shown in Fig. $1 \mathrm{H}$, $5 \mathrm{mM}$ L-NAME increased, whereas $50 \mu$ M DETA-NO decreased, the percentage of mononucleated cells. In addition, DETA-NO increased the formation of binucleated cells and multinucleated myotubes, whereas L-NAME reduced the number of myotubes.

The results reported in Fig. 1 demonstrate that the activity of NOS and generation of NO are tightly regulated during satellite cell differentiation and that NO triggers and enhances fusion without influencing other events in the differentiation program of these cells. The fact that exogenous NO is not effective when NOS is inhibited suggests that NO signaling is regulated not only at the level of its generation by NOS but also downstream of it. clase inhibitor $1 H-(1,2,4)$ oxadiazolo [4,3- $\alpha]$ quinoxalin-1-one (ODQ; $3 \mu \mathrm{M}$ ), which were administered in the 4-24-h time window in which these cells generate cGMP. Satellite cell fusion was measured after $72 \mathrm{~h}$. As shown in Fig. 2 (C-E), 8 BrcGMP and ODQ mimicked the effects of DETA-NO and L-NAME, respectively. In addition, the fusogenic effect of DETA-NO, although insensitive to L-NAME, was abrogated by ODQ. ODQ, however, did not affect fusion stimulated by $8 \mathrm{Br}$-cGMP. These results clearly indicate that the effect of NO on satellite cell fusion depends on activation of guanylate cyclase and generation of cGMP.

The results depicted in Fig. 1 suggest that NO signaling is regulated not only at the level of its generation by NOS but also downstream of it. The results in Fig. 2, showing the cGMP dependence of the effect of NO and the time-dependent changes in the sensitivity of guanylate cyclase to NO, indicate that this regulatory step downstream of NOS activity is at the level of guanylate cyclase.

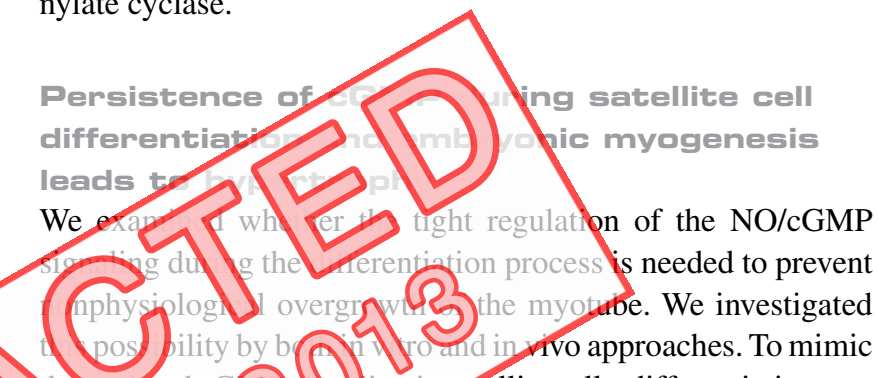

The effect of NO on satellite cell fusion depends on a controlled generation of cGMP

We next analyzed the dependence of the effects of activation of guanylate cyclase and generation portant signaling event mediating severd o b im of NO (Moncada et al., 1991). As shov Fig A, durentiation of satellite cells in culture is ampoied d Jeneration

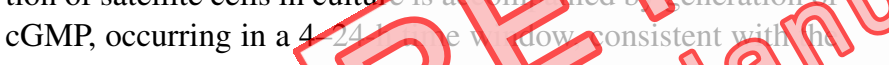
time window of the effec Fine The goles cGMP was NO dependent fausexposyof didentiating cells to $5 \mathrm{mM}$ L-NAME on $50 \mathrm{MM} \mathrm{DF} \Omega$ grministered for $30 \mathrm{~min}$ at each of the time points indica 2 il Fig $2 \mathrm{~A}$ inhibited or enhanced, respectively, gen ration of cGMP. Of importance, the ability of DETA-NO to increa the yclic nucleotide was significantly higher when it was admmistered during the first $12 \mathrm{~h}$ of the differentiation process. It thereafter declined to a point similar to that of nondifferentiated cells (Fig. 2 A, compare time $72 \mathrm{~h}$ with time 0 ). These results suggest that in satellite cells sensitivity of guanylate cyclase to NO is regulated and its activation favored in the initial phases of differentiation. Because the levels of expression of the two guanylate cyclase subunits $\alpha$ and $\beta$ did not change with time (Fig. 2 B), it appears that such regulation occurs through posttranslational events.

To assess the role of cGMP generation in satellite cell fusion, we studied the effect of the cell membrane-permeant cGMP analogue $8 \mathrm{Br}-\mathrm{cGMP}(0.3-5 \mathrm{mM})$ and the guanylate cy-

ration dependent, as it was the increase in myosin expression (Fig. $3 \mathrm{C}$ ). The myotubes in $8 \mathrm{Br}$-cGMP-treated cultures were considered to be hypertophic because their mean nuclei number and fiber dimension (Fig. 3 B) and the total amount of myosin (Fig. 3 C) were significantly higher compared with controls and were increased by the cyclic nucleotide in a concentrationdependent way. Such hypertrophy and increase in myosin were not observed in satellite cells differentiated in the presence of 50-300 $\mu$ M DETA-NO, even at the higher concentrations tested (Fig. 3, A-C; and not depicted).

Satellite cell differentiation occurs through signaling pathways similar but not identical to those observed during embryonic skeletal muscle development (Charge and Rudnicki, 2004). We therefore evaluated the role of the NO-cGMP pathway and of its deregulation in embryonic and fetal myogenesis. Presomitic mesoderm (PSM) or the most caudal somites (I-III) from the myosin light chain promoter $1 / 3$ fast (MLC1/3F)nLacZ 9.5-d postcoitum transgenic mouse embryos, in which

treated with $3 \mathrm{mM} 8 \mathrm{Br}$-cGMP. Results shown are representative of four reproducible experiments. (E) Fusion index, measured in the same conditions as detailed in Fig. 1. ${ }^{*}, \mathrm{P}<0.05 ;{ }^{* *}, \mathrm{P}<0.001$ versus $\mathrm{NT}(n=4)$. (F) X-Gal staining of MLC1/3F-nLacZ embryos, developed in the absence (left) or presence (right) of $8 \mathrm{Br}$-cGMP $(3 \mathrm{~g} / \mathrm{kg}$ body weight) administered through the pregnant mother from E10.5 to either E12.5 (top and middle) or E15.5 (bottom). The areas selected in red in the top panels are enlarged in the middle panels. Arrows show larger and more elongated fibers, indicating an increased level of myogenesis. Results are representative of three reproducible experiments. Error bars represent SEM. Bars: (A) $150 \mu \mathrm{m}$; (D) $125 \mu \mathrm{m}$; $(F$, top) $1.5 \mathrm{~mm}$; (F, middle) $500 \mu \mathrm{m}$; $(F$, bottom) $1 \mathrm{~mm}$. 
the LacZ gene is under the transcriptional control of MLC1/3F (Kelly et al., 1995), were grown as explants in cultures in the presence or absence of 50-300 $\mu \mathrm{M}$ DETA-NO, 1-3 mM $8 \mathrm{Br}$-cGMP, or $5 \mathrm{mM}$ L-NAME. After only $2 \mathrm{~d}$ in cultures, differentiated mononucleated myocytes emerged from the PSM explants, and these increased in number after an additional $2 \mathrm{~d}$ (Fig. 3, D and E). Neither 50-300 $\mu$ M DETA-NO nor L-NAME had relevant effects on the time of appearance and the number of myocytes after $4 \mathrm{~d}$ at any concentration tested (Fig. 3, D and $\mathrm{E}$; and not depicted); in contrast, $3 \mathrm{mM} 8 \mathrm{Br}$-cGMP triggered formation of myotubes, an event that does not occur physiologically in PSM explant cultures (Cossu and Biressi, 2005), indicating that the cyclic nucleotide was able to break the fusion restriction in the PSM and myotome (Fig. 3 D). The effect of 8 Br-cGMP was concentration dependent (Fig. 3 E). Similar results were observed in somite explants (unpublished data).

To study myogenesis during late embryonic and fetal development, MLC1/3F-nLacZ pregnant females were treated with or without $8 \mathrm{Br}$-cGMP ( $3 \mathrm{~g} / \mathrm{kg}$ body weight) from gestation day 10 to either 12.5 or 15.5. Embryos were then recovered, and myogenic cells were revealed by LacZ staining. As shown in Fig. 3 F, 8 Br-cGMP-treated embryos showed enhanced LacZ staining, indicating an increased level of myogenesis at both time points considered. These results clearly indicate that continuous presence of cGMP increases myotube size /nd results in muscle hypertrophy and that the tight regulation concentration is required for a normal myogenic rre

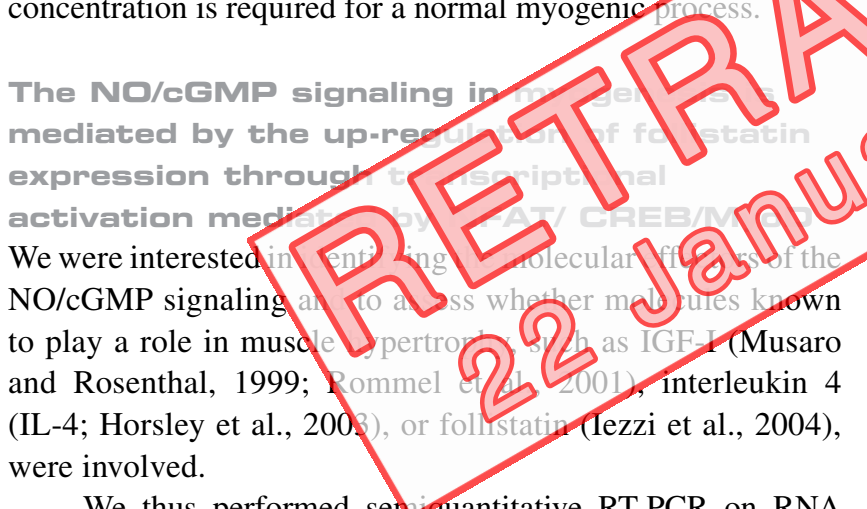

We thus performed senrquantitative RT-PCR on RNA isolated from differentiated satellite cells, PSM explants, or muscle from embryonic and fetal stages that were treated or untreated with $3 \mathrm{mM} 8 \mathrm{Br}$-cGMP, $50 \mu \mathrm{M}$ DETA-NO, or $5 \mathrm{mM}$ L-NAME using primer specific for IGF-I, IL-4, follistatin, myostatin, and skeletal muscle-specific MLC1/3F (Fig. $4 \mathrm{~A}$ ). In parallel, we examined the expression of IGF-I, IL-4, follistatin, myostatin, and sarcomeric myosin heavy chain by Western blotting (Fig. 4 B). Quantitative assessment and statistical analyses of the results obtained are shown in Fig. S1 (available at http://www.jcb.org/cgi/content/full/jcb.200507083/DC1).

Although L-NAME had no effects in all conditions, we observed an increased level of myosin light chain transcripts and protein from $8 \mathrm{Br}$-cGMP- and DETA-NO-treated cultures and embryos. In satellite cells, this was accompanied by a marked increase in follistatin expression at both the mRNA and protein levels. Of importance, in PSM explants and embryos, follistatin expression was increased only in the presence of 8 Br-cGMP, whereas DETA-NO had no significant effect
A

A

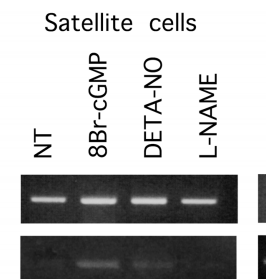

E 9.5 explants

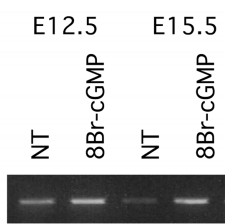

IGF-I

Follistatin
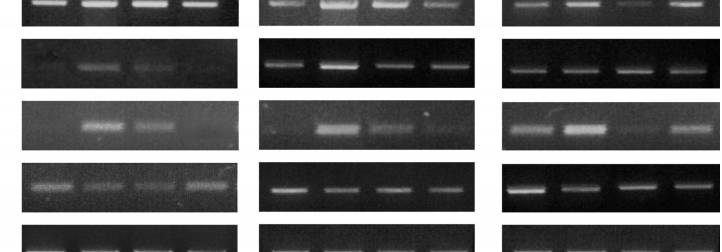

Myostatin

GAPDH
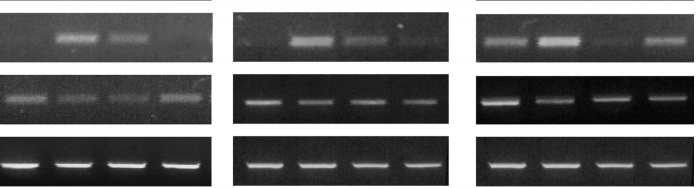

$\mathrm{B}$

Satellite cells $\quad$ E15.5

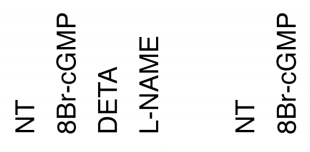

\section{$\sum_{\substack{1 \\ \hline 1}}$}
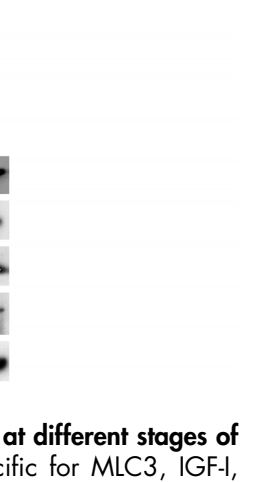

Nofle de Jopme on gene expression at different siages of
RT-PCR using primets specific for MLC3, IGF-I, 9.5 SM expants, muS tis dissected from E12.5 and E15.5 mouse s, differen i Joresence of L-NAME, $50 \mu \mathrm{M}$ DETA-NO, or three reproduci experiments. (B) Expression of sarcomeric myosin, follistaf myolain, gad GAPDH determined by Western blotting using s Cif tibodies on satellite cells and muscle tissue from E15.5 embryos, 2) Uren the presence of $5 \mathrm{mM}$ L-NAME, $50 \mu M$ DETA-NO, or . $(3 \mathrm{mM}$ or $3 \mathrm{~g} / \mathrm{kg}$ body weight). Results are representative of reproducible experiments.

(Fig. 4 and Fig. S1). Myostatin protein levels were not significantly affected, even if there was a decrease in mRNA levels. We also observed that the mRNA and protein levels of IGF-I were slightly increased by $8 \mathrm{Br}$-cGMP. These changes, however, were not significant (Fig. 4 and Fig. S1). No changes in the levels of IL-4 were detected (unpublished data). These results suggest that increased generation of follistatin is relevant to the NO/cGMP signaling during myoblast differentiation.

Follistatin has recently been described to be a central mediator of the fusogenic effects exerted by deacetylase inhibitors on myoblast fusion into preformed myotubes through a pathway distinct from those used by either IGF-I or IL-4 (Iezzi et al., 2004). In particular, regulation of follistatin by deacetylase inhibitors, such as trichostatin A (TSA), appeared to be cooperatively activated by MyoD, nuclear factor of activated $\mathrm{T}$ cells (NFAT), and cAMP response element binding protein (CREB; Iezzi et al., 2004).

To investigate whether the NO-cGMP pathway activated the follistatin promoter by the same pathway, we used the myogenic cell line $\mathrm{C} 2 \mathrm{C} 12$, which was also used in Iezzi et al. (2004). Similar to satellite cells, C2C12 myoblasts gave rise to hypertrophic myotubes when cultured in the constant presence of 8 Br-cGMP (Fig. 5, A and B). This was accompanied by 
concentration-dependent increases in the levels of follistatin (Fig. 5 C). To study the effect on follistatin transcription, the follistatin promoter linked to the luciferase gene (Fs-Luc) was transfected in C2C12 cells (Iezzi et al., 2004). 8 Br-cGMP activated transcription of Fs-Luc (Fig. 5 D). To establish whether the activation of follistatin promoter by cGMP was mediated by MyoD, CREB, and NFAT, Fs-Luc-transfected C2C12 were differentiated in the presence of $8 \mathrm{Br}-\mathrm{cGMP}$ and/or transfected with the negative regulator of MyoD; Id1 (Iezzi et al., 2004); or the dominant-negative form of CREB, A-CREB (Herzig et al., 2001), or VIVIT, which is a peptide that blocks NFAT-dependent transcription (Aramburu et al., 1999). We observed that the 8 Br-cGMP-dependent activation of Fs-Luc was inhibited in the presence of any of these inhibitors (Fig. 5 D). Thus, NFAT, MyoD, and CREB mediate the effects of 8 Br-cGMP on follistatin transcription. Previous studies in other cell types showed that CREB and NFAT are activated by cGMP through a protein kinase G-dependent phosphorylation (Gudi et al., 1996; Pilz and Casteel, 2003; Gonzalez Bosc et al., 2004). Accordingly, we found that $3 \mu \mathrm{M}$ each of two structurally unrelated protein kinase G inhibitors, KT5823 and 8-(chlorophenylthio)guanosine-3', 5' - cyclic monophosphorothioate ([Rp]-8-pCPT-cGMPS; Smolenski et al., 1998), prevented the induction of Fs-Luc transcription by cGMP (Fig. 5 D). In smooth muscle, cGMP may act through protein kinase $\mathrm{A}$, an enzyme that plays a role in selected myogenic pathways (Cornwell et al., 1994; Chen et al. 2005 The possible involvement of protein kinase $\mathrm{A}$ in me effects of cGMP, however, was excluded by the la hibil tory effects by $3 \mu \mathrm{M}$ of the protein kinase and (Rp)-8-pCPT-cAMPS (Fig. 5 D) We then studied whether hie
listatin transcription or of the small but detectab ang in the lasels of 1 tran scripts induced by 8 Br-cGM Fig. 4). (SP ayed both satellite and $\mathrm{C} 2 \mathrm{C} 12$ cells in differentjating conlesence of $8 \mathrm{Br}$-cGMP and of either antibydies direcled ganst follistatin to neutralize its activity (Iezzi et al 2004) or the phosphatidylinositol 3' kinase inhibitor LY294002, which inhibits IGF-I signaling in muscle (Ibarra et al., 2004). In addition, we used the small interference RNA approach already shown to silence follistatin expression in C2C12 cells (Iezzi et al., 2004). The neutralizing follistatin antibodies inhibited the action of $8 \mathrm{Br}-\mathrm{cGMP}$ without significant effects on its own in both satellite (Fig. 5, A and E) and $\mathrm{C} 2 \mathrm{C} 12$ cells (Fig. 5 B). Cell transfection with the small linterfering RNA against follistatin consistently inhibited the effect of $8 \mathrm{Br}-\mathrm{cGMP}$ in $\mathrm{C} 2 \mathrm{C} 12$ cells (Fig. S2, available at http://www.jcb.org/cgi/content/full/jcb.200507083/DC1). These results indicate that the effect of cGMP is mostly mediated by the activation of follistatin. Consistent with this, LY294002 did not modify the effects of $8 \mathrm{Br}$-cGMP while inhibiting those of IGF-I in both satellite cells and $\mathrm{C} 2 \mathrm{C} 12$ (Fig. $5 \mathrm{~F}$ and not depicted). To assess the cell specificity of the effect of cGMP on follistatin, we investigated whether it also increased follistatin expression in cells belonging to nonmuscle lineages, namely embryonic carcinoma cells (P19) undergoing neuronal differentiation, adult (NIH 3T3) and embryonic (10 T1/2) fibroblast cell lines, mesoangioblast-derived smooth muscle progenitors (D351; Brunelli et al., 2004), and primary cultures of cardiomyocytes. 8 Br-cGMP had no effects on follistatin levels in any of these cells, whereas it consistently increased follistatin induction in $\mathrm{C} 2 \mathrm{C} 12$ cells used as control (Fig. S3, available at http://www.jcb.org/cgi/content/full/jcb.200507083/DC1).

\section{iscussion}

Skeletal muscle mass growth and maintenance is controlled principally through the regulation of myofiber size both during embryogenesis and in postnatal life. This regulation occurs through two main and distinct mechanisms. One relies on the regulation of the cytoplasmic volume associated with individual myonuclei, and this pathway appears to involve regulation of protein synthesis and of protein degradation (Glass, 2003; Stitt et al., 2004). The second mechanism involves the control of the number of myonuclei within a myofiber. In this case, the growth of the muscle fiber during fetal and postnatal development depends on the addit cells, embryonic or fetal myoblast and satelline resp ively, that must be instructed when to divice entiate by either fusing with preexilin pers amomselves to generate a new fiber Myobla Jusion is 1 (S) id akelam (O) ales have beer antifie as playing a role in one or more of these 1 ses, including IL-4, IGFs, integrins, and metallo(2)des alliano et al., 2000; Rommel et al., 2001; Horsley (0),2003, Schwander et al., 2003; Yi et al., 2005). The mechahisms and signaling pathways underlying the role of these molecules controlling myoblast fusion, however, have yet to be fully elucidated.

We demonstrate that the generation of NO is crucial to myoblast fusion in mammals. We found that the action of NO has several important characteristics. (a) It appears to have an effect at critical stages of pre- and postnatal muscle development life. (b) It works through the same signaling pathway at all stages, i.e., activation of guanylate cyclase, with generation of cGMP and induction of follistatin. (c) It is specific to the fusion process itself because NO did not affect cellular differentiation and/or proliferation. This defines for the first time a common trigger for fusion and is the first evidence indicating that the fusion process may take place through the same activating process in both the embryo and the newborn.

Another important aspect of the pathway to muscle fusion activated by NO emerging from our results is that it is a regulated process. We have studied it in detail in satellite cells. We found that the regulation of NO effects on muscle fusion occurred at two distinct early steps of the signaling cascade, i.e., the enzymatic activities of NOS and guanylate cyclase, which were regulated in the absence of detectable changes in protein levels. The regulation of guanylate cyclase appears to be particularly important because activation of the enzyme could not be increased even by administration of exogenous NO. We have not yet identified which events among the ones proposed to 

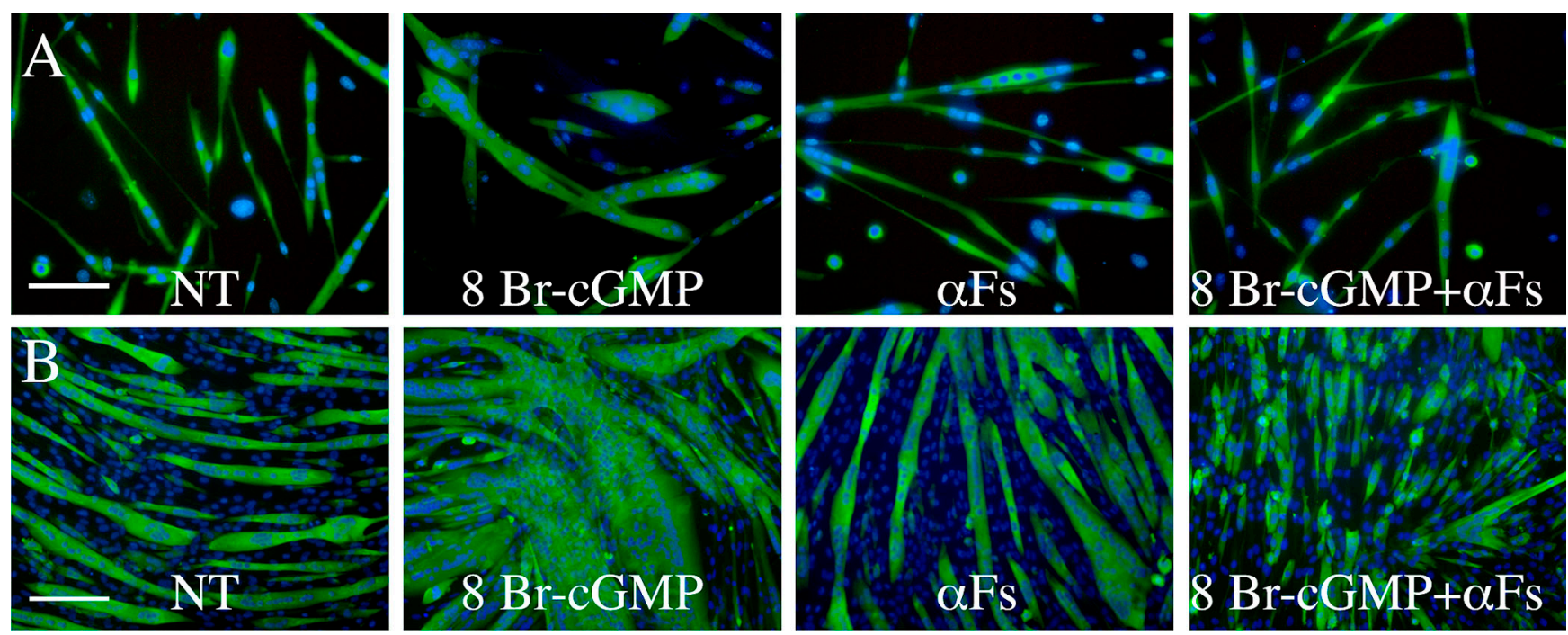

$\mathrm{C}$

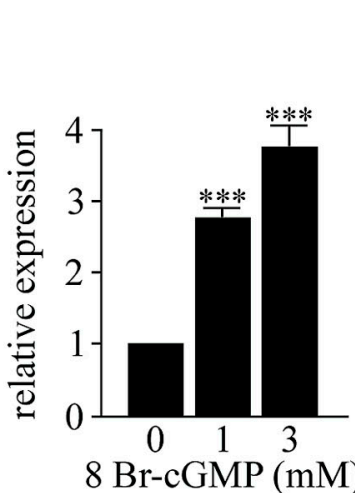

$\mathrm{E}$

8 Br-cGMP $(\mathrm{mM})$

E

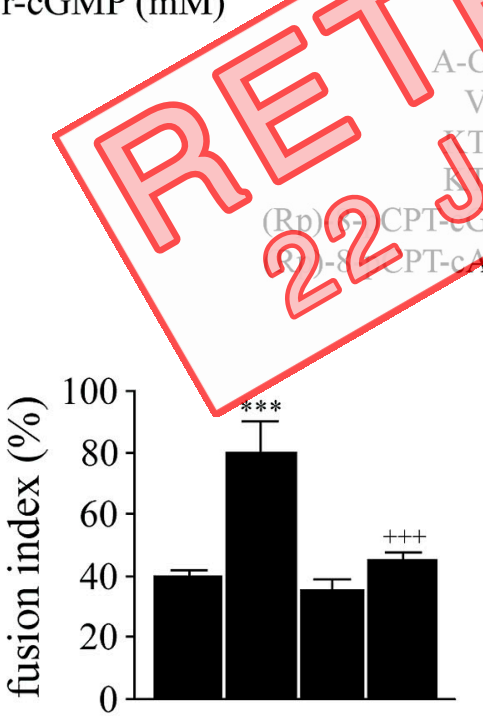

$8 \mathrm{Br}-\mathrm{cGMP}-+-+$

$\alpha$-Follistatin $-\quad+++$

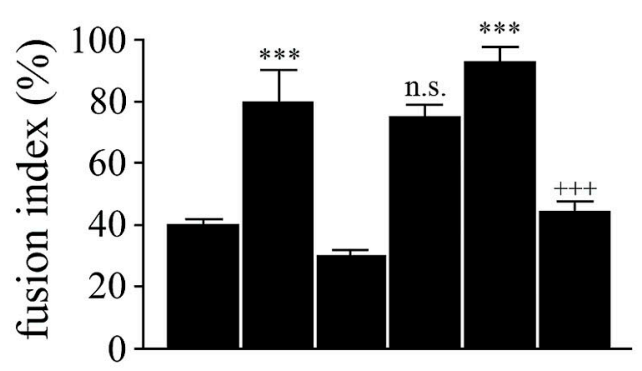

$8 \mathrm{Br}-\mathrm{cGMP}-+-+-$

LY $294002-\quad++-+$

IGF-I $\quad-\quad-\quad-\quad-\quad+\quad+$

Figure 5. NO/cGMP increase expression of follistatin. Satellite (A, E, and F) and $C 2 C 12$ cells (B-D) were differentiated for $48 \mathrm{~h}$ in the presence or absence (NT) of $8 \mathrm{Br}-\mathrm{cGMP}$ ( $3 \mathrm{mM}$, where not otherwise indicated), $4 \mu \mathrm{g} / \mathrm{ml}$ anti-follistatin antibody $(\alpha \mathrm{Fs}), 5 \mu M$ LY294002, or $10 \mathrm{ng} / \mathrm{ml}$ IGF-I in various combinations as indicated. (A and B) Representative images of four reproducible experiments after staining with the anti-myosin MF20 mAb (green, FITC) and the nuclear dye Hoechst (blue). (C) Same as in B, except that C2C12 cells were lysed and mRNA analyzed by real-time PCR. (D) Same as in B except that $\mathrm{C} 2 \mathrm{C} 12$ cells were previously transfected with Fs-Luc and transfected with or without Id I, A-CREB, or VIVIT before differentiation or treated with $3 \mu M$ KT5823, $3 \mu$ M KT5720, $3 \mu M$ (Rp)-8-pCPT-cGMPS, or $3 \mu \mathrm{M}$ (Rp)-8-pCPT-cAMPS. Expression of Fs-Luc was quantified by chemiluminescence. (E and F) Satellite cell fusion index in the various conditions. ${ }^{* * *}, \mathrm{P}<0.001$ versus controls; $\dagger, \mathrm{P}<0.001$ versus 8 Br-cGMP-treated cells $(n=3)$. Error bars represent SEM. Bars: (A) $100 \mu \mathrm{m}$; (B) $200 \mu \mathrm{m}$. 
induce desensitization of guanylate cyclase to NO, e.g., phosphorylation by protein kinases or even a direct action of NO itself (Bellamy et al., 2000; Friebe and Koesling, 2003), play a role in the desensitization observed here. The physiological relevance of this event, however, is clear because deregulation of cGMP signaling leads to muscle hypertrophy both in satellite cells and in the embryo. More strikingly, myoblasts differentiating from the PSM, known to be incompetent for fusion (Cossu and Biressi, 2005), acquire such competence in the presence of cGMP, suggesting that the NO-cGMP pathway not only is crucial to stimulating fusion but also may confer competence to it. Whether and how this occurs when the mononucleated myocytes of the myotome are incorporated into newly formed primary fibers remains to be studied.

Of the three NOS isoforms, murine (and human) skeletal muscles express the constitutive NOS I $\mu$ and III, whereas expression of the inducible NOS II is clearly detected only in the presence of inflammation or other pathological conditions (Thompson et al., 1996; Stamler and Meissner, 2001). Accordingly, we found that satellite cells and skeletal muscle from embryos (unpublished data) express NOS I $\mu$ and III. However, it is conceivable that both enzymes may play a role because both NOS I $\mu$ and III are activated by increases in intracellular calcium concentrations, and NOS III is also activated by Akt (Alderton et al., 2001), i.e., signaling events triggered by many myogenic stimuli (Guttridge, 2004; Horsley and Pavlath, 2004 In addition, no obvious defects in muscle developnent har been reported in NOS I or III knockout mice. Also this respect is the observation that expressio

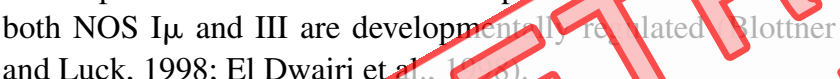
and Luck, 1998; El Dwairi et 2l.,

NO/cGMP-dependent fu D in a nit new to skeletal muscle biology. Riss is a pein tod inleract with and regulates the biolgo activit $(9)$ yeral TGE $\beta$ family members, including BMP-4, BMI- 1 actions (Iemura et al., 1998; Amthor et al., 2008). Follistann has been also found to block the activity of myostatin a negarne regulator of skeletal muscle mass, thus leading to muscle hypertrophy (Lee and McPherron, 2001). Therefore, the connection of this protein with NO/cGMP identifies an endogenously activated pathway for follistatin induction that can be activated by many myogenic stimuli and defines the role of $\mathrm{NO}$ in the process of fusion.

The pathway of follistatin induction by NO/cGMP was found to involve MyoD, NFAT, and CREB. Previous work has demonstrated that both CREB and NFAT are directly activated by NO/cGMP through protein kinase G-dependent phosphorylation (Gudi et al., 1996; Fiedler et al., 2002; Pilz and Casteel, 2003; Gonzalez Bosc et al., 2004). The fact that inhibition of protein kinase $\mathrm{G}$ prevented follistatin induction by cGMP is consistent with these results and further confirms the role of CREB and NFAT. We found that expression of MyoD is not affected by NO/cGMP; whether this transcription factor is activated by NO/cGMP through phosphorylation, similar to other MyoD activating stimuli, remains to be established. The biological significance of each of these transcription factors in mediating the effect of NO/cGMP, however, clearly emerges from our results because each of them was found to be necessary to follistatin induction. Indeed, specific inhibition of MyoD, NFAT, or CREB was sufficient to prevent the transcriptional function of cGMP. Furthermore, these results suggest that the transcriptional effects of NO/cGMP may be more complex than previously envisaged. The fact that MyoD, CREB, and NFAT appear to be necessary to mediate the transcriptional effect of NO/cGMP resembles the situation already described for stimulation of myoblast fusion by the deacteylase inhibitor TSA (Iezzi et al., 2004). The similarity between the action of TSA and NO/cGMP and the recent evidence showing that TSA is able to up-regulate the expression of NOS III in nonendothelial cells (Fish et al., 2005; Gan et al., 2005 ) suggests that NO/cGMP is involved in regulating the process of acetylation. Interestingly, the effect of NO/cGMP, similar to that of TSA (Iezzi et al., 2004), was restricted to cells of skeletal muscle origin. This cell specificity is intriguing, and the mechanisms beyond it need to be investigated further.

In conclusion, the link emerging here among the NO/cGMP signaling and follistatin ind ctio an important event during prenatal and adult myosen of this messenger may be brence havid ly envisaged and at the crossroad of differen ys central to skeletal muscle developro and enegtion. The acton mediated through eb 1 in maliso synergize wh other known acIS O1NO, s J as activati $\Omega$ satellite cens (Anderson, 2000; sum al., 2002 Y 1 , the GMP-dependent inducCollista) (b) interact with other cGMP-independent aions of $\mathrm{NO}^{\mathrm{O}}$ thy play a role in muscle development, such as inbin of cytochrome $c$ oxidase and control of mitochon6. Spidtion and $S$-nitros(yl)ation (Stamler and Meissner, 2(, Moneada and Erusalimsky, 2002).

\section{Materials and methods}

\section{Materials}

The following reagents were purchased as indicated: ODQ and DETA-NO from Alexis Italia, KT5823 and KT5720 from Calbiochem, and (Rp)-8-pCPTcGMPS and -cAMPS from Biolog. The following mAbs were purchased as indicated: anti-NOS-I $\mu$ and anti-NOS-III mAbs from BD Biosciences, antiglyceraldehyde 3-phosphate dehydrogenase (GAPDH) mAb from Biogenesis, anti-PCNA mAb from Santa Cruz Biotechnology, Inc., anti-MyoD mAb from DakoCytomation, anti-sarcomeric myosin MF20 mAb from Developmental Studies Hybridoma Bank, anti-follistatin mAb (AF669) from R\&D Systems, and anti-myostatin (ab996) and anti IGF-I (ab12517) antibodies from AbCAM. In immunofluorescence analysis, primary antibodies were detected by appropriate FITC-conjugated secondary antibodies (Southern Biotechnology Associates, Inc.). In immunoblot analysis, primary antibodies were detected by chemiluminescence with appropriate horseradish peroxidase-conjugated secondary antibodies, all purchased from BioRad Laboratories. Cell culture media and sera were purchased from Cambrex. $\mathrm{L}\left[{ }^{3} \mathrm{H}\right]$-arginine and the kits for the enhanced chemiluminescence and the CGMP radioimmunoassay were obtained from GE Healthcare. Bicinchoninic acid-based assay was obtained from Perbio; $\mathrm{C} 2 \mathrm{C} 12$ cells were obtained from American Type Culture Collection; and the anti-desmin polyclonal antibody, L-NAME, 8 Br-CGMP, LY294002, IGF-I, and the Hoechst dye and other chemicals were obtained from Sigma-Aldrich. DETA-NO was always prepared fresh by dissolving it at $\mathrm{pH} 7.4$ for $20 \mathrm{~min}$ before addition to the cell samples. Under these conditions, DETA-NO generates NO constantly and at defined concentrations (Clementi et al., 1998).

\section{Cell cultures}

Satellite cells were isolated from 3-5-d-old mice as described previously (Cossu et al., 1980) with some modifications. In particular, after $3 \mathrm{~d}$ of isolation, proliferating myoblasts were harvested, counted, and plated on 
tissue culture plastic dishes coated with $1 \mathrm{mg} / \mathrm{ml}$ type I collagen. After $2 \mathrm{~d}$ of proliferation in growth medium, myogenic cells accounted for $>90 \%$ of the cultures as revealed by anti-desmin immunostaining assay. Preparation showing $<90 \%$ myogenic cells were discarded. Myoblasts were shifted to differentiating medium in the presence or absence of drugs as indicated in Results. Growth medium contained Iscove's modified Dulbecco's medium supplemented with $20 \%$ FBS, $3 \%$ chick embryo extract (Cossu et al., 1987), $100 \mathrm{U} / \mathrm{ml}$ penicillin, $100 \mu \mathrm{g} / \mathrm{ml}$ streptomycin, and $50 \mu \mathrm{g} / \mathrm{ml}$ gentamycin. Differentiation medium contained Iscove's modified Dulbecco's medium supplemented with $2 \%$ horse serum, $100 \mathrm{U} / \mathrm{ml}$ penicillin, and $100 \mu \mathrm{g} / \mathrm{ml}$ streptomycin. Fusion index was determined as the number of nuclei in sarcomeric myosin-expressing cells with more than two nuclei versus the total number of nuclei.

C2C12 cells were cultured in DME supplemented with $15 \%$ FBS, $100 \mathrm{U} / \mathrm{ml}$ penicillin, and $100 \mu \mathrm{g} / \mathrm{ml}$ streptomycin and differentiated in DME supplemented with $2 \%$ horse serum, $100 \mathrm{U} / \mathrm{ml}$ penicillin, and 100 $\mu \mathrm{g} / \mathrm{ml}$ streptomycin as described previously (lezzi et al., 2004).

\section{Immunofluorescence}

Immunofluorescence on cells and explants was performed as described previously (Brunelli et al., 2004), using the following antibodies: MF20 (1:3) and anti-desmin (1:400).

\section{Protein extraction and immunoblot analysis}

Cells were washed free of medium and solubilized by direct addition of a preheated $\left(\right.$ to $80^{\circ} \mathrm{C}$ ) denaturing buffer containing $50 \mathrm{mM}$ Tris- $\mathrm{HCl}, \mathrm{pH} 6.8$, $2 \%$ sodium dodecyl sulfate, and a Complete protease inhibitor cocktail (Roche) and immediately boiled for $2 \mathrm{~min}$ as previously described (Bulotta et al., 2001). Alternatively, muscle tissues from embryos were dissected and homogenized in $50 \mathrm{mM}$ Tris/ $\mathrm{HCl}$, pH 7.4, 1 mM EGTA, $1 \mathrm{mM}$ EDTA, $1 \%$ Triton X-100, and Complete protease inhibitor cocktail and centrifuged $(1,000 \mathrm{~g})$ for $20 \mathrm{~min}$ at $20^{\circ} \mathrm{C}$ to discard cellular debris. For secreted pro teins analysis, supernatants were collected and concentrated as describe previously (Corradi et al., 1996). After addition of $0.05 \%$ brom phe blue, $10 \%$ glycerol, and $2 \% \beta$-mercaptoethanol, samples again and loaded onto $10 \%$ SDS-polyacrylamide gel sis, polypeptides were electrophoretically transferred (Schleicher \& Schuell) and antigens were respective primary and secondary antib.

Assay of NOS activity The time course of NOS conversion of $\mathrm{L}\left[{ }^{3} \mathrm{H}\right]-\mathrm{grs}$ (Bulotta et al., 2001). In $5 \mathrm{mM} \mathrm{KCl}, 1 \mathrm{mMMgSO}$ $\mathrm{pH}$ 7.4. $10 \mu \mathrm{Ci} / \mathrm{ml} \mathrm{l}_{-}\left[{ }^{3} \mathrm{H}\right]-\mathrm{d}$ and the reaction was stopped mented with $5 \mathrm{mM}$ l-arginine was added to the dishes and $20 \mathrm{mM}$ Hepes, pH 6.0. L-NAMEof specificity. Separation of $\mathrm{L}-\left[{ }^{3} \mathrm{H}\right]-$ citulline hom $\mathrm{L}-\left[{ }^{3} \mathrm{H}\right]$-arginine was performed by DOWEX 50X8-400 chromatography. $\mathrm{L}-\left[{ }^{3} \mathrm{H}\right]$-citrulline formed was normalized to protein content and evaluated by the bicinchoninic acid procedure.

\section{Measurement of cGMP generation}

At each time point, satellite cell cultures were incubated for $30 \mathrm{~min}$ at $37^{\circ} \mathrm{C}$ either in growth or in differentiation media with $0.5 \mathrm{mM}$ of the phosphodiesterase inhibitor 3-isobutyl-1-methylxanthine supplemented with $50 \mu \mathrm{M}$ DETA-NO, $5 \mathrm{mM}$ L-NAME, or vehicle. The reaction was terminated by rapid medium removal and washing with ice-cold PBS and was lysed by the addition of ice-cold trichloroacetic acid (final concentration: 6\%). After ether extraction, cGMP levels were measured using a radioimmunoassay kit and normalized to protein content.

\section{Embryo explants culture}

PSM and most of the five caudal somites were dissected, together with fragmentation of the neural tube from $\mathrm{MLCl} / 3 \mathrm{~F}$ E9.5 embryos, and cultured as explants, as described previously (Cossu et al., 1996). Differentiation was continued for 2-4 $\mathrm{d}$ in the presence of various drugs, as described in Results. Before the immunofluorescence assay, X-Gal staining was performed according to standard protocols (Brunelli et al., 2003).

\section{Animal treatments}

$\mathrm{MLCl} / 3 \mathrm{~F}$ pregnant females were treated with or without $8 \mathrm{Br}-\mathrm{cGMP} / 3 \mathrm{~g} / \mathrm{kg}$ body weight; administered in drinking water) from gestation day 10 to 12.5 or 15.5 . Embryos were then recovered, and myogenic cells were re- vealed by X-Gal staining (see Embryo explants culture). Animals were housed in the pathogen-free facility at the Stem Cell Research Institute (Milan, Italy) and treated in accordance with the European Community guidelines and with the approval of the Institutional Ethical Committee.

\section{RT-PCR}

$1 \mu \mathrm{g}$ RNA was collected from cells, dissected embryos, or tissues using RNeasy mini (or micro) kit (QIAGEN) and was converted into doublestranded cDNA by reverse transcription using the cDNA synthesis kit Thermoscript RT-PCR system (Invitrogen) according to the manufacturer's instructions. CDNA was then amplified using the following primers: follistatin forward, CTCTTCAAGTGGATGATTTTC, and reverse, ACAGTAGGCATTATTGGTCTG; GAPDH forward, TGAAGGTCGGAGTCAACGGATTTGGT, and reverse, CATGTGGGCCATGAGGTCCACCAC; IGF-1 forward, GTGGATGCTCTTCAGTTCGT, and reverse, ACACTCCTAAAGACGATGTT; IL4 forward, AACCCCCAGCTAGTTGTCATCCTG, and reverse, CATCGAAAAGCCCGAAAGAGTCTC; MLC3F forward, GATCACCTTAAGTCAGGT, and reverse, GCAACGCTTCTACCTCTT; myostatin forward, AGCCTGAATCCAACTTAGGC, and reverse, GGTGCACAAGATGAGTATGC.

\section{Plasmids and transfections}

$500 \mathrm{bp}$ of the rat follistatin proximal promoter linked to the luciferase was derived from the 2.8-Kb rat follistatin promoter-luciferase construct (Bilezikiian et al., 2001). Id, VIVI, and A-CREB expression vectors have been described before (lezp et 2004). The transfections were performed with the FuGENEb ro (Roche). Luciferase assay on cell lysates was performed as descr pre (lezzi et al., 2004).

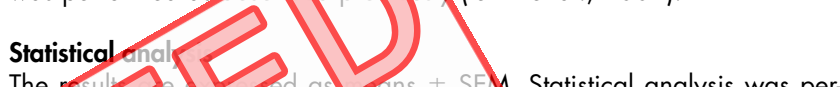
The resul Se Statistical analysis was perorm ro a tost for unpaited variables. Asterisks and

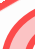
$p$ ob ility vaves of 45 co babilities, measured in the the figure legends. Statistical me acquis (8) Wanipulgion

Images in fluor Nika Jan flu $4 \times 10.13,10 \times 10.33,20 \times / 0.50$, and $40 \times 10.75)$ and Pf Se- trast imgges of embryos on stereomicroscope (SMZ1500; Nikon; 2 id bes an apochromatic $1 \times$ WD54, eyepiece lens CW 10 $/ 22$ ). - 3 images were acquired using a digital camera (DXM1200; Nikon) and the acquisition software ACT-1 (Nikon), imaging medium, PBS buffer, and loom temperature. Images were assembled in panels using Photoshop 7.0 (Adobe). Images showing double fluorescence (FITC and Hoechst) were first separately acquired using the different appropriate filters and then merged with Photoshop 7.0.

\section{Online supplemental material}

Fig. S1 shows the densitometric quantification of RT-PCR and Western blots analysis shown in Fig. 4. Fig. S2 shows that inhibition of follistatin expression by RNA interference abolishes the effect of NO/cGMP on fusion-induced muscle hypertophy in $\mathrm{C} 2 \mathrm{C} 12$. Fig. $\mathrm{S} 3$ shows that the NO/cGMP effect on follistatin induction is specific to skeletal myoblasts. Supplemental text describes the methods used in the RNA interference and in the culture of cardiomyocytes and of $\mathrm{C} 3 \mathrm{H} 10 \mathrm{Tl} / 2, \mathrm{NIH}$ 3T3, P19, and D351 cells. Online supplemental material is available at http://www. jcb.org/cgi/content/full/jcb. 200507083/DCl.

This work was supported by grants from Telethon, the European Community, Duchenne Parent Project Italia, The Istituto Superiore di Sanità, the Italian Ministry of Health, the Italian Ministry of University and Research, Fondazione Cariplo, the Italian Association of Cancer Research, and the Intramural Research Program of the National Institute of Arthritis and Musculoskeletal and Skin Diseases of the National Institutes of Health.

Submitted: 18 July 2005

Accepted: 16 December 2005

\section{References}

Alderton, W.K., C.E. Cooper, and R.G. Knowles. 2001. Nitric oxide synthases: structure, function and inhibition. Biochem. J. 357:593-615.

Amthor, H., B. Christ, F. Rashid-Doubell, C.F. Kemp, E. Lang, and K. Patel. 2002. Follistatin regulates bone morphogenetic protein-7 (BMP-7) activity to stimulate embryonic muscle growth. Dev. Biol. 243:115-127. 
Anderson, J.E. 2000. A role for nitric oxide in muscle repair: nitric oxide-mediated activation of muscle satellite cells. Mol. Biol. Cell. 11:1859-1874.

Aramburu, J., M.B. Yaffe, C. Lopez-Rodriguez, L.C. Cantley, P.G. Hogan, and A. Rao. 1999. Affinity-driven peptide selection of an NFAT inhibitor more selective than cyclosporin A. Science. 285:2129-2133.

Balemans, W., and W. Van Hul. 2002. Extracellular regulation of BMP signaling in vertebrates: a cocktail of modulators. Dev. Biol. 250:231-250.

Balon, T.W., and J.L. Nadler. 1997. Evidence that nitric oxide increases glucose transport in skeletal muscle. J. Appl. Physiol. 82:359-363.

Bellamy, T.C., J. Wood, D.A. Goodwin, and J. Garthwaite. 2000. Rapid desensitization of the nitric oxide receptor, soluble guanylyl cyclase, underlies diversity of cellular cGMP responses. Proc. Natl. Acad. Sci. USA. 97:2928-2933.

Bilezikjian, L.M., A.Z. Corrigan, A.L. Blount, Y. Chen, and W.W. Vale. 2001 Regulation and actions of Smad7 in the modulation of activin, inhibin, and transforming growth factor- $\beta$ signaling in anterior pituitary cells. Endocrinology. 142:1065-1072.

Blottner, D., and G. Luck. 1998. Nitric oxide synthase (NOS) in mouse skeletal muscle development and differentiated myoblasts. Cell Tissue Res. 292:293-302.

Bredt, D.S. 1998. NO skeletal muscle derived relaxing factor in Duchenne muscular dystrophy. Proc. Natl. Acad. Sci. USA. 95:14592-14593.

Brunelli, S., E. Casey, D. Bell, R. Harland, and R. Lovell-Badge. 2003. Expression of Sox 3 throughout the developing central nervous system is dependent on the combined action of discrete, evolutionarily conserved regulatory elements. Genesis. 36:12-24.

Brunelli, S., E. Tagliafico, F.G. De Angelis, R. Tonlorenzi, S. Baesso, S. Ferrari, M. Niinobe, K. Yoshikawa, R.J. Schwartz, I. Bozzoni, and G. Cossu. 2004. Msx2 and necdin combined activities are required for smooth muscle differentiation in mesoangioblast stem cells. Circ. Res. 94:1571-1578.

Buckingham, M., L. Bajard, T. Chang, P. Daubas, J. Hadchouel, S. Meilhac, D Montarras, D. Rocancourt, and F. Relaix. 2003. The formation of skeletal muscle: from somite to limb. J. Anat. 202:59-68.

Bulotta, S., R. Barsacchi, D. Rotiroti, N. Borgese, and E. Clementi. 2001 tion of the endothelial nitric-oxide synthase by tumor necr alpha. A novel feedback mechanism regulating cell deatb 276:6529-6536.

Charge, S.B., and M.A. Rudnicki. 2004. Cellular a muscle regeneration. Physiol. Rev. 84:209

Chen, A.E., D.D. Ginty, and C.M. Fan via CREB controls myogen 433:317-322.

Chen, E.H., and E.N. Olson fusion in Drosophila.

Clementi, E., and J. Meldole and $\mathrm{Ca}^{2+}$ : a story with a Pharmacol. Sci. 18:266-260

Clementi, E., G.C. Brown, M. Feelisch, and S. Mo 1998 Persistent inhibition of cell respiration by nitric oxide: crucial re of $S$-nitrosylation of mitochondrial complex I and profective action of glutathione. Proc. Natl. Acad. Sci. USA. 95:7631-7636.

Cornwell, T.L., E. Arnold, N.J. Boerth, and T.M. Lincoln. 1994. Inhibition of smooth muscle cell growth by nitric oxide and activation of cAMPdependent protein kinase by cGMP. Am. J. Physiol. 267:C1405-C1413.

Corradi, N., B. Borgonovo, E. Clementi, M. Bassetti, G. Racchetti, G.G Consalez, W.B. Huttner, J. Meldolesi, and P. Rosa. 1996. Overall lack of regulated secretion in a PC12 variant cell clone. J. Biol. Chem. 271:27116-27124.

Cossu, G., and S. Biressi. 2005. Satellite cells, myoblasts and other occasional myogenic progenitors: possible origin, phenotypic features and role in muscle regeneration. Semin. Cell Dev. Biol. 16:623-631.

Cossu, G., B. Zani, M. Coletta, M. Bouche, M. Pacifici, and M. Molinaro. 1980 In vitro differentiation of satellite cells isolated from normal and dystrophic mammalian muscles. A comparison with embryonic myogenic cells. Cell Differ. 9:357-368.

Cossu, G., F. Eusebi, F. Grassi, and E. Wanke. 1987. Acetylcholine receptor channels are present in undifferentiated satellite cells but not in embryonic myoblasts in culture. Dev. Biol. 123:43-50.

Cossu, G., R. Kelly, S. Tajbakhsh, S. Di Donna, E. Vivarelli, and M. Buckingham. 1996. Activation of different myogenic pathways: Myf5 is induced by the neural tube and MyoD by the dorsal ectoderm in mouse paraxial mesoderm. Development. 122:429-437.

Cusella-De Angelis, M.G., S. Molinari, A. Le Donne, M. Coletta, E. Vivarelli, M. Bouche, M. Molinaro, S. Ferrari, and G. Cossu. 1994. Differential response of embryonic and fetal myoblasts to TGF $\beta$ : a possible regulatory mechanism of skeletal muscle histogenesis. Development. 120:925-933.
El Dwairi, Q., Y. Guo, A. Comtois, E. Zhu, M.T. Greenwood, D.S. Bredt, and S.N. Hussain. 1998. Ontogenesis of nitric oxide synthases in the ventilatory muscles. Am. J. Respir. Cell Mol. Biol. 18:844-852.

Eu, J.P., J.M. Hare, D.T. Hess, M. Skaf, J. Sun, I. Cardenas-Navina, Q.A. Sun, M. Dewhirst, G. Meissner, and J.S. Stamler. 2003. Concerted regulation of skeletal muscle contractility by oxygen tension and endogenous nitric oxide. Proc. Natl. Acad. Sci. USA. 100:15229-15234.

Fiedler, B., S.M. Lohmann, A. Smolenski, S. Linnemuller, B. Pieske, F. Schroder, J.D. Molkentin, H. Drexler, and K.C. Wollert. 2002. Inhibition of calcineurin-NFAT hypertrophy signaling by cGMP-dependent protein kinase type I in cardiac myocytes. Proc. Natl. Acad. Sci. USA. 99:11363-11368.

Fish, J.E., C.C. Matouk, A. Rachlis, S. Lin, S.C. Tai, C. D'Abreo, and P.A. Marsden. 2005. The expression of endothelial nitric-oxide synthase is controlled by a cell-specific histone code. J. Biol. Chem. 280:24824-24838.

Friebe, A., and D. Koesling. 2003. Regulation of nitric oxide-sensitive guanylyl cyclase. Circ. Res. 93:96-105.

Galliano, M.F., C. Huet, J. Frygelius, A. Polgren, U.M. Wewer, and E. Engvall. 2000. Binding of ADAM12, a marker of skeletal muscle regeneration, to the muscle-specific actin-binding protein, $\alpha$-actinin-2, is required for myoblast fusion. J. Biol. Chem. 275:13933-13939.

Gan, Y., Y.H. Shen, J. Wang, X. Wang, B. Utama, and X.L. Wang. 2005. Role of histone deacetylation in cell-specific expression of endothelial nitricoxide synthase. J. Biol. Chem. 280:16467-16475.

Glass, D.J. 2003. Signalling pathways hat mediate skeletal muscle hypertrophy and atrophy. Nat. Cell Bi

Gonzalez Bosc, L.V., M.K Bradley, D.M. Eckman, D.C. HillEubanks, and 2004. Traminal pressure is a stimulus for NFATc3 perle ent calcium, endothelium-derived nitric 1 protein kinase. J. Biol. Chem. M.M. Lohmann, G.R. Boss, and R.B. Pilz. 1996.

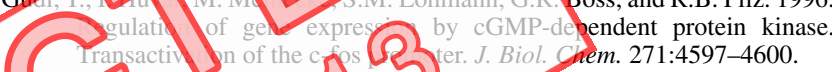

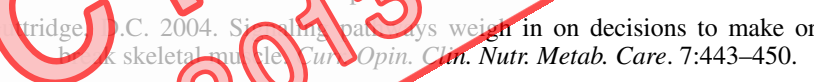
. col nesis hrough the coactivator PGC-1. Nature. 413:179-183.

ale (V., S I G.K Pavlath. 2004. Forming a multinucleated cell: molecules 0 Ut re mate moblast fusion. Cells Tissues Organs. 176:67-78. K.M. Jansen, S.T. Mills, and G.K. Pavlath. 2003. IL-4 acts as a myoblast recruitment factor during mammalian muscle growth. Cell. 113:483-494. a, C., M. Estrada, L. Carrasco, M. Chiong, J.L. Liberona, C. Cardenas, G. Diaz-Araya, E. Jaimovich, and S. Lavandero. 2004. Insulin-like growth factor-1 induces an inositol 1,4,5-trisphosphate-dependent increase in nuclear and cytosolic calcium in cultured rat cardiac myocytes. J. Biol. Chem. 279:7554-7565.

Iemura, S., T.S. Yamamoto, C. Takagi, H. Uchiyama, T. Natsume, S. Shimasaki, H. Sugino, and N. Ueno. 1998. Direct binding of follistatin to a complex of bone-morphogenetic protein and its receptor inhibits ventral and epidermal cell fates in early Xenopus embryo. Proc. Natl. Acad. Sci. USA. 95:9337-9342.

Iezzi, S., M. Di Padova, C. Serra, G. Caretti, C. Simone, E. Maklan, G. Minetti, P. Zhao, E.P. Hoffman, P.L. Puri, and V. Sartorelli. 2004. Deacetylase inhibitors increase muscle cell size by promoting myoblast recruitment and fusion through induction of follistatin. Dev. Cell. 6:673-684.

Kaliman, P., J. Canicio, X. Testar, M. Palacin, and A. Zorzano. 1999. Insulin-like growth factor-II, phosphatidylinositol 3-kinase, nuclear factor- $\mathrm{B}$ and inducible nitric-oxide synthase define a common myogenic signaling pathway. J. Biol. Chem. 274:17437-17444.

Kelly, R., S. Alonso, S. Tajbakhsh, G. Cossu, and M. Buckingham. 1995. Myosin light chain $3 \mathrm{~F}$ regulatory sequences confer regionalized cardiac and skeletal muscle expression in transgenic mice. J. Cell Biol. 129:383-396.

Lee, K.H., M.Y. Baek, K.Y. Moon, W.K. Song, C.H. Chung, D.B. Ha, and M.S. Kang. 1994. Nitric oxide as a messenger molecule for myoblast fusion. J. Biol. Chem. 269:14371-14374.

Lee, S.J., and A.C. McPherron. 2001. Regulation of myostatin activity and muscle growth. Proc. Natl. Acad. Sci. USA. 98:9306-9311.

Moncada, S., and J.D. Erusalimsky. 2002. Does nitric oxide modulate mitochondrial energy generation and apoptosis? Nat. Rev. Mol. Cell Biol. 3:214-220.

Moncada, S., R.M. Palmer, and E.A. Higgs. 1991. Nitric oxide: physiology, pathophysiology, and pharmacology. Pharmacol. Rev. 43:109-142.

Musaro, A., and N. Rosenthal. 1999. Maturation of the myogenic program is induced by postmitotic expression of insulin-like growth factor I. Mol. Cell. Biol. 19:3115-3124. 
Nisoli, E., S. Falcone, C. Tonello, V. Cozzi, L. Palomba, M. Fiorani, A. Pisconti, S. Brunelli, A. Cardile, M. Francolini, et al. 2004. Mitochondrial biogenesis by NO yields functionally active mitochondria in mammals. Proc. Natl. Acad. Sci. USA. 101:16507-16512.

Ontell, M., and K. Kozeka. 1984. The organogenesis of murine striated muscle: a cytoarchitectural study. Am. J. Anat. 171:133-148.

Parker, M., P. Seale, and M.A. Rudnicki. 2003. Looking back to the embryo: defining transcriptional networks in adult myogenesis. Nat. Rev. Genet. 4:497-507.

Pilz, R.B., and D.E. Casteel. 2003. Regulation of gene expression by cyclic GMP. Circ. Res. 93:1034-1046.

Relaix, F., D. Rocancourt, A. Mansouri, and M. Buckingham. 2005. A Pax3/ Pax7-dependent population of skeletal muscle progenitor cells. Nature. 435:948-953.

Rommel, C., S.C. Bodine, B.A. Clarke, R. Rossman, L. Nunez, T.N. Stitt, G.D. Yancopoulos, and D.J. Glass. 2001. Mediation of IGF-1-induced skeletal myotube hypertrophy by $\mathrm{PI}(3) \mathrm{K} / \mathrm{Akt} / \mathrm{mTOR}$ and $\mathrm{PI}(3) \mathrm{K} / \mathrm{Akt} / \mathrm{GSK} 3$ pathways. Nat. Cell Biol. 3:1009-1013.

Schwander, M., M. Leu, M. Stumm, O.M. Dorchies, U.T. Ruegg, J. Schittny, and U. Muller. 2003. Beta1 integrins regulate myoblast fusion and sarcomere assembly. Dev. Cell. 4:673-685.

Smolenski, A., A.M. Burkhardt, M. Eigenthaler, E. Butt, S. Gambaryan, S.M. Lohmann, and U. Walter. 1998. Functional analysis of cGMP-dependent protein kinases I and II as mediators of NO/cGMP effects. Naunyn Schmiedebergs Arch. Pharmacol. 358:134-139.

Stamler, J.S., and G. Meissner. 2001. Physiology of nitric oxide in skeletal muscle. Physiol. Rev. 81:209-237.

Stitt, T.N., D. Drujan, B.A. Clarke, F. Panaro, Y. Timofeyva, W.O. Kline, M. Gonzalez, G.D. Yancopoulos, and D.J. Glass. 2004. The IGF-1/PI3K/Akt pathway prevents expression of muscle atrophy-induced ubiquitin ligases by inhibiting FOXO transcription factors. Mol. Cell. 14:395-403.

Tajbakhsh, S. 2003. Stem cells to tissue: molecular, cellular and anatomical heterogeneity in skeletal muscle. Curr. Opin. Genet. Dev. 13:413-422.

Tatsumi, R., A. Hattori, Y. Ikeuchi, J.E. Anderson, and R.E. Allen. 2002 of hepatocyte growth factor from mechanically stretched ske satellite cells and role of $\mathrm{pH}$ and nitric oxide Mol. Biol. 13:2909-2918.

Thompson, M., L. Becker, D. Bryant, G. William , D r L B.P. Giroir. 1996. Expression of the ind in diaphragm and skeletal muscle

Wakelam, M.J. 1985. The fusion of nyo

Wang, T., Z. Xie, and B. Lu. suppression at deye

Wolosker, H., J.B. Rocha S Meis. 1997. Sarco/en responses to acidosi mid culum $\mathrm{Ca}^{2+}$-ATPage olms: diverse

Yi, H., J. Gruszczynska-Biegala, Dood ( ) ha A. Zokiewska. 2005. Cooperation of the metplloprotease, by cysteine-rich domains of ADAM12 during inhibition 1 lyogepic differentiation. J. Biol. Chem. 280:23475-23483.

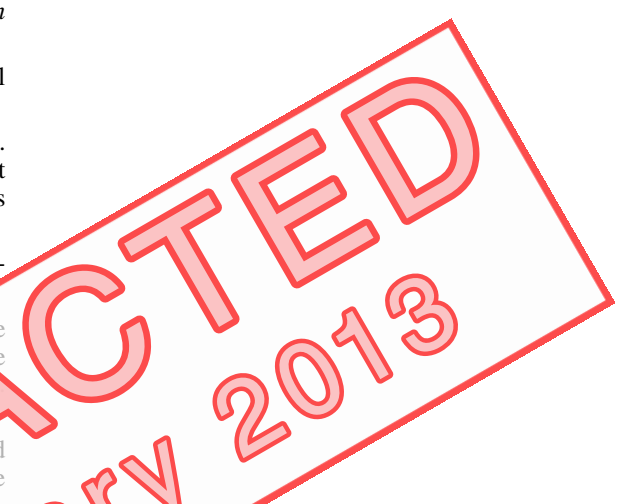

